\title{
The Process of Self-actualization in Altair From The Anime Re:Creator by Ei Aoki
}

\author{
Muhammad Agrisandy Satyarso ${ }^{1}$ \\ ${ }^{1}$ Faculty of Humanities, Diponegoro University
}

\begin{abstract}
This thesis is aimed to analyses the process of self-actualization from a main antagonist character called Altair, from the anime series titled Re:Creators. Based on Abraham Maslow's theory of Hierarchy of Needs. The data that was used in order to determine the process of selfactualization in the main antagonist Altair, were the 21 episodes in the animation series of Re:Creators. The method used in this thesis is the analytic descriptive method, and the theories to support the result of the analysis are Himawan Pratista's Movie Narratives Structure theory and Abraham Maslow's Hierarchy of Needs. The result of this thesis is that the main antagonist Altair achieves her self-actualization. Unlike any other human character, due to her nature of being a "creation", an "omnipotent" character and not a normal human being, makes the process of selfactualization quite hard to determine. However, she managed to achieved her self-actualization by gathering allies to support her cause, survived being hunted by the protagonist, and at a intense final battle that took place in Tokyo's district of Ginza, Altair once again managed to meet her long passed creator Setsuna Shimazaki .
\end{abstract}

Keywords: Movie Narrative Structure, Anime, Abraham Maslow's Hierarchy of Needs.

\section{Introduction}

The definition of literature often changes and is very subjective. Some consider literature as written works in general, while some are art forms that could entertain and teach us. In the case of this paper, the writer believed the work of pieces of literature is an art form that encompasses many forms. A literature work could be in the form of prose fiction, drama, and poetry. Literature has been a source of human entertainment from millennia ago. In the words of the ancient Greece philosopher Plato stated in Nasrullah's article, literature is an art, like painting, sculpture, and others. [1]

\footnotetext{
*Corresponding author: agrisandy@gmail.com
} 
Literature Literature has diversified itself into many forms throughout human history. One of those forms is a work such as animation. The development of animation or motion pictures was believed to have started from ancient Egyptian inlined pictures. However, an animation with cinematography in mind just appeared in human history at the earliest around the 1800s. In Japan, animation has just appeared for the public eyes to see as early as 1907. Famous first Japan's known animation work such as Katsudou Shashin (活動写 真) showed a depiction of a young sailor boy doing daily activity. In Japan, a work of animation is being called animation (アニメションアニメ) or anime (アニメ) for short. Until the present, the development and fame of Japanese anime have grown significantly throughout the years.

With the positive feedback from many viewers and critics alike, the anime industry has grown so fast that it became a worldwide phenomenon in just a decade. Japan also has decided to put their anime as part of the Japan Cool culture movement. Many people around the world come to Japan because of the influence of anime culture alone. Throughout the year Japan anime industry has created or produced some of the best animation works known in the international market. In just a year, the industry could produce the amount of hundreds or two hundred anime to watch. By 2020, the total amount of Japan anime industry managed to produce has reached around 4505 anime. In one of those numbers, one anime is particularly unique in theme and approach to its characters; it is titled the Re: Creators.

$R e$ : Creators is an original anime that was produced by the TROYCA studio in the year 2017. This anime is directed by a producer named Ei Aoki and has 22 episodes in total that consist of around 24 minutes worth of durations each episode. Re: Creators First aired on the Tokyo MX channel on the 8th of April 2017. This anime has a genre of fantasy, sci-fi, and action. This anime series is telling a story about an omnipotent powerful 'creation' named Altair, who is the main antagonist of this series, causing a clash of dimensions between the real world and creation world for wanting to take revenge against the real world for allowing or causing the death of her creator named Setsuna Shimazaki. Altair fought off against challenging adversities and used many tactics to beat her opponent and claim a victory to achieve her goals. Although she is described as a powerful being, she still shows her human side to the audience. This paper aims to analyze the process of her selfactualization as a character. [2]

In order to analyze a character's self-actualization, Abraham Maslow's hierarchy of need theory could help the process. In Maslow's hierarchy of needs theory, creatures like humans need to accomplish five stages of needs to reach their self-actualization fully. Five of those needs are physiological, safety, love and belonging, esteem, and self-actualization. [3]

\section{Research Methods}

Since the material for this paper is in the form of anime, this research paper is considered a literature research study. In this literature research paper, there are two types of research techniques to be used. Those two types are narration and qualitative description. Which involve these following procedures or methods to accomplish the analysis parts of this research.

1. Observation: Due to the nature of anime as a video, the need to observe by watching every episode containing data mine to help the research is a must. Image of places, characters, and events that are happening in the anime need to be observed. 
2. Classification: When good data mining by observation has been conducted successfully, the data in hand will soon be classified into its category.

3. Analysis: After the classification process is completed. The next step will be analyzing the data at hand. In order to obtain the most accurate data, secondary books, a thesis, and a paper are essential to support findings..

4. Interpretation: For adequately understanding the context of the analyzed data, interpretation is required.

5. Description: After all the previous methods have been conducted, the description method will be used to describe the context of the analyzed data.

\section{Theories}

In order to obtain the most accurate and valid data from the material, theories are required. Two theories could help obtain accurate analysis results. Because Re: Creators is an anime, then to analyze the narrative's structural structure, a structural narration theory will be the correct theory to analyze it. As for the self-actualization of Altair's character, a hierarchy of needs theory would be required.

\subsection{Narrative Structure Theory}

Himawan Pratista, in his book, explains that a narrative element is a material. In a film, the thing that can be considered a narrative element is the storytelling, while cinematic elements are a style that a producer of a film uses to produce a work of film. Himawan also, in his book Memahami Film stated that narrative is a channel of events that connected in a logical cause and effect of environmental and time situations. Himawan believed in his book that the following elements are responsible for a film narrative structure. [4]

\subsubsection{Plot and Storyline}

The plot is a part of the story that has the form of a channel of events that is shown or aired in a film in the form of audio and visual. Not all parts of a story will be adapted into a film, but only a handful few. The plot reflects behavior that a story's characters show, such as how they take action and speak to deal with specific problems or struggles.

\subsubsection{Space Relation to a Narrative}

Space is a place or environment of activities for characters or events to take place. A space used in a story could be in a natural form or a fictional form of an environment such as a room, pool, hallway, and fictional heaven.

\subsubsection{Time Relation to a Narrative}

There are two essential aspects of time about a narrative structure.

1. Time Sequences

A time sequence can be divided into two types. The first one is a linear time sequence, and the second one is a non-linear time sequence. A linear time sequence is a plot moving linearly that can be interpreted into an A-B-C-D-E sequence. A non-linear time sequence is a plot where the cause and effect affect the flow of the time and story as a whole.

2. Duration 
Duration could be interpreted into two different meanings. The first is the duration of the whole series of film or movie itself, and the second is the time inside the story itself, such as how many weeks or even years passed inside the film storyline.

\subsubsection{Characters}

Characters can be divided into two roles: the main characters and the second is the supporting role. There is also a role such as a protagonist and an antagonist. The character's role in a story is very vital. If there are no characters to play a role, then a story could not progress.

\subsubsection{Problems and Conflicts}

Problems and conflicts are adversities that hold the main characters to reach their goal. Problems are usually caused by the opposing role of the antagonist due to different reasons and goals than the one protagonist believed.

\subsubsection{Goal}

In every story, there are goals that a protagonist and antagonist alike have to reach some point in the story. Without a goal, a story would become meaningless. The goal can be in the form of physical or non-physical (abstract). An example of a physical goal includes a character's dreams to have better living quarters, money, or lover. While as for the nonphysical, it could be in the form of an ideology, religious believes, etc.

\subsection{Hierarchy of Needs}

Maslow, in Koeswara's book, explains that humans as living beings have never been in a situation where they are delighted. For humanity, satisfaction is only temporary. If a need has been fulfilled and satisfied, other needs will force ask for fulfillment. By judging by this, Maslow suggested that human needs are things humanity brought with them since their first existence and are stacked in a hierarchy. The hierarchy of needs can be divided into five needs according to Maslow's theory; those needs are as follow.

\subsubsection{Physiological Needs}

The physiological need is a need that is required to be maintained in order for an individual to be able to survive physically. For example, the need to drink, eat, and sleep is one that humans need to fulfill for surviving.

\subsubsection{Need for Self-security or Safety}

When the physiological need of an individual has been fulfilled, the following need is safety needs. Maslow thinks that a need for safety is a need that pushes an individual to obtain peace, confirmation, and a rule on the environment.

\subsubsection{Need for Love and Belonging}

The need for love and belonging is an individual need to acquire companionship, a sense of love, and affection in general. 
The need for self-esteem is a way to give an individual how good or far they consider themselves as a person. Maslow, in Koeswara's book, stated that self-esteem could be divided into two types.

1. Self-respect.

This encompasses feelings such as self-competence, self-confidence, freedom, etc.

2. Respect from others.

An individual can obtain this by winning an award that makes other individuals respect that individual.

\subsubsection{Self-actualization}

Inside in Abraham Maslow's theory of hierarchy of needs, the need for expressing oneself or self-actualization is placed on the very top of the hierarchy of needs. This need will appear when an individual fully achieves all the previous needs. For an individual to achieve their self-actualization, they usually have to deal against two types of adversities. The first type is adversity that comes from inside one individual, such as overcoming selfdoubt, the scared of using full potential, etc. The second type is adversity that took the form of negative thoughts. These negative thoughts were born from the extreme need for safety. An example can be taken, such as the difficulty of an individual to overcome their negative habits.

\section{Analysis}

On this analysis part the narrative structure and Altair's self-actualization will be analysed then described in a very compact manners.

\subsection{Narrative Structure Theory}

\subsubsection{Story and Plot}

The story of Re: Creators is started by the death of Setsuna Shimazaki, creator of Altair. This event is the sole reason why Altair came to the real world to enact revenge on the natural world people she called Gods for did the most horrible thing to her creator Shimazaki. In the first episode, she asked or tried to manipulate Selesia, another creation, to go to the real world to make her "God" pays for the turmoil which occurred in her world Earthmilia. However, Selesia refused Altair and considered her as her enemy. When that happened, Souta was accidentally thrown into Selesia's world and got caught amid a battle between Selesia and Altair. Realizing that Souta was there, Selesia saved him from Altair's attack and got transferred to the real world, where they continued to fight and met with another creation named Meteora. Meteora, one of the two characters who know how the clash between dimensions works, explains to Souta and Selesia what is currently happening. She suggested that Souta tell many famous anime, manga, and games writers alike to be informed about the current event. Meteora theorized that if a specific character from a particular fictional world has high fame, then the chances of that character being summoned by Altair or the cracks between the two worlds are far higher than those who are not. This theory can be proven by the appearances of characters such as Alicetaria or Yuya, considered the most popular from their respective fictional world.

With the increasing appearances of multiple creations being, aside was formed. The side of Altair, who is hoping to destroy the world, and the side of Meteora, who is hoping to save 
It. One day, another character creation appeared inside the real world. The person is named Magane, and compared to the other creation characters; she is the only one who managed to damage the real world by murdering two people. With her appearances in the world, the race to acquire her started by the Altair and Meteora side. This race results in a highly intense battle between the two sides and intensifies the conflict at hand. The conflict heightens between Meteora and Alicetaria after the death of Mamika in the hands of Altair. Magane has deceived Alicetaria about Mamika's death that Meteora was the one responsible. The next fight ended with both Selesia and Meteora gravely wounded because of Alicetaria and Altair.

The conflict of Re: Creators reached its finale when almost every character of creation on Altair's side decided to betray her in the final battle of Elimination Chamber Fest. Altair, in this battle, shows everyone her true power to defeat the alliance of Meteora. In the process, Altair met her clone named Sirius, who managed to corner her and subsequently erased her existence to $0 \%$. However, Altair regained her existence by exploiting Sirius's little background as a character and fusing with her body, creating Altair 2.0. The fan around Japan who are watching the battle happening support Altair more than the alliance of Meteora. This, in turn making Altair becoming even more powerful and unstoppable. As the battle becomes unwinnable for the alliance, Souta asks Meteora to use his creation against Altair. That creation turns out to be Setsuna Shimazaki, Altair's creator herself.

The appearance of Setsuna made Altair shaken. Altair, who does not believe that Setsuna comes back from the dead, threatens to kill her. However, she could not make herself do it in the end. Setsuna explains everything about how Altair became exists and is more robust in the process. After the explanations from Setsuna, Altair knew that she was doing the wrong thing because she did not realize that she did not exist because of Setsuna's hatred toward the world. However, she exists because Setsuna made Altair be loved and accepted by many. Unbeknown to everyone, the sound of the train suddenly can be heard moving closer to them. A train of fate has once again tried to erase Setsuna from the world. Altair, who does not want this to happen again, saved Setsuna. The plot has reached its end as Altair and Setsuna are forever together in a world with infinite possibilities.

\subsubsection{Space Relation to Narrative}

Re:Creators took place in modern Tokyo, Japan and for a brief moment a fictional world called Earthmilia Selesia's home world. Some other place included below.

1. Park somewhere in Tokyo

2. Souta's house

3. Matsubara's workplace company

4. Dilapidated house, factory, and church

5. Japanese government conference hall

6. Tokyo Dome stadium

7. Tokyo, Ginza.

\subsubsection{Time Relation to Narrative}

\section{Time Sequence}

Re:Creators is using a linear time line plot. The plot of the story is going on a straight line that kept rising through time and then drop down because there is a solution to the story. The type of plot line which Re:Creators using is A-B-C-D-E.

2. Durations (Video duration \& Story timeline) 
Re:Creators have 24 minutes of time each episode and inside story's time started at October 2016 and ended at $23^{\text {rd }}$ of July 2017 with three different season (fall, winter, \& summer) played in the background of the story.

\section{4,4,4 Characters}

Below are the list of characters who are contributing on the story the most.

1. Main Characters
a) Souta Mizushino (hero)
b) Meteora Osterreich (True-Heroine)
c) Selesia Yupitiria (False-Heroine)
d) Altair (Female Antagonist)

2. Side Characters
a) Alicetaria February
b) Mamika Kirameki
c) Setsuna Shimazaki
d) Yuya Mirokuji
e) Magane Chikujoin
f) Blitz Talker

\subsubsection{Problems and Conflicts}

Below has been listed the problems and conflicts that happened in Re:Creators as part of the plotline.

1. Altair trying to break the rule between the real world and fictional world.

2. Setsuna Shimazaki death starts a conflict between Altair and the real world.

3. The difference on how to view the real world and creators between Altair and Meteora sparks a bloody battle.

4. Altair true goal has been discovered and the betrayal of Alicetaria, Blitz, and Shou.

\subsubsection{Goal}

In a story there are certainly a goal that a character need to accomplished for the sake of the progression of a story. In this anime there are three goals that Altair's the main antagonist seeks to accomplished.

1. Seeking vengeance against people of the real world for treating Setsuna wrongly.

2. Destroying the rule and law between the real world and fictional world.

3. Be together again with Setsuna in a world where Altair made.

\subsection{Hierarchy of Needs}

\subsubsection{Physiological Need}

As a creative being considered a demigod, Altair can achieve her physiological needs differently from other fully human creations. There are two ways that Altair can do or get to fulfill her physiological needs. One of them can be achieved by using her power of Holopsicon to maintain her physical body in the real world that rejects her very fictional nature. Her fame can achieve the second one in the eyes of people in the real world. If, for example, people in the real world could be convinced and accept that Altair is somehow dead, this will directly affect Altair's living physical body as people believe her to be dead, however, since many people are convinced. Moreover, accept Altair's existence in the fictional world, then Altair can exist in both natural and fictional worlds. This is stated on Re: Creators episode 20th. 


\subsubsection{Need for Self-security or Safety}

As stated in the physiological needs section, Altair needs to maintain her physiological body from being rejected by the natural world's rules of nature. This can be done by simply using her holopsicon power, but she also needed to avoid frontal conflict with Meteora and others. This is because more frontal conflict involving herself could make the nature of the natural world reject her and delete her existence from the real world. To avoid those unwanted conflicts and to wait until she could freely do her own will in the real world, Altair is required to hide her presence from Meteora and her allies in dilapidated buildings scattered around the prefecture of Tokyo. This, in turn, gives her a sense of security and safety. Having an ally could also fulfill Altair's safety need because Altair could be more at ease knowing that someone would defend her with someone behind her back.

\subsubsection{Need for Love and Belonging}

Altair's need for belonging has already been achieved by fulfilling her need for safety. These belonging are in the form of allies that she could rely on on the battlefield. Her allies such as Alicetaria, Blitz, Shou, and Charon can give her a sense of security and something to protect until she eventually disposes of them. Altair's need for love has already been achieved since the beginning of her real world, which the natural world peoples accept. Up until episode 21st, where Setsuna explains how Altair could exist and become powerful, Altair never realized that she exists due to overwhelming love and acceptance given by the natural world people. When Altair realized this, she became a very different person. As if her positive emotion has just awoken.

\subsubsection{Need for Esteem}

There are two types of self-esteem. The first is the self-confidence that Altair has. Altair, on episode 17th, showed her self-confidence by effortlessly deflecting the most potent attack that Selesia could muster and mocking the creation of the others who defy her as weaklings. This is a sign of her high self-confidence. The second type of self-esteem is the one that was given to Altair. This type of self-esteem can be traced in episode 20th, where Altair can be seen getting full support by the audiences of Elimination Chamber Fest to defeat the Meteora alliance because she showed a pretty death-defying and physics \& logic-defying power when up against Selesia and co.

\subsubsection{Self-actualization}

The need for self-actualization in Altair has been achieved in episode 21. The first hindrance that comes from inside herself is afraid of losing her creator Setsuna, again. She managed to overcome the fear of losing her creator by willingly trying to self-sacrifice to save Setsuna from getting hit by the train of fate. The second hindrance of her selfactualization comes in action where she uses herself instead of others to save Setsuna. This means that she overcame the comfort of being the one who asked others to do things and became the one who tried to do things, in this case, saving Setsuna.

Altair also fulfills her potential as a powerful creation to become a literal god-like being by influencing those who support her as a creative being throughout her existence. 


\section{Conclusions}

In conclusion, the plot story of Re: Creators tells about the crack of dimension where the fictional world's character emerged from their world to the real world because of Altair. Altair does this to create an imbalance between the two realms so that it causes destruction. This is due to Setsuna, Altair's creator, who died miserably due to mistreatment and bullying in cyberspace. Altair, who did not accept the actual world's treatment toward her creator, decided to break the rule of physics and start summoning fellow creations such as Meteora, Selesia, Alicetaria, Yuya, and others to the real world. This anime's plotline can be considered an A-B-C-D-E pattern due to its linear story with one past scene that does not affect the whole narration sequence. The problem in this anime is that Altair is trying to end the world by mistreating Setsuna and Souta Mizushino, and Meteora to defend the world from Altair's wrath, which ended on both Altair's sides. Meteora's side has a peaceful ending to its problems.

The next one is a representation of Altair by the process of self-actualization of Abraham Maslow. Altair can fulfill her physiological needs by using her power holopsicon to manipulate her physical self so that it does not get rejected by the rule of the world. Altair's fame in the real world also plays a part in her physical self as it is the core reason she exists in the first place. The need for safety has been accomplished by staying out of direct conflict with Meteora in a dilapidated building somewhere in Tokyo, Japan. Altair's need for safety has also been accomplished by summoning other creations such as Charon, Shou, and Alicetaria as an ally for her and those prepared to protect her. After the need for safety is fulfilled, the following hierarchy of needs that has been fulfilled is the love and belonging of Altair. Altairs need for belonging is in the form of her allies who are willing to battle for her goal. At the same time, the need for love is fulfilled by those who support her, in this case, her fans and her creator Setsuna.

The last two hierarchies of needs that Altair had fulfilled are self-esteem and selfactualization. For Altair's self-esteem, she fulfilled it by the power that makes her invulnerable, making the confidence inside her come into existence. The other self-esteem is the one that Altair earns from the support of her growing fans in the real world. The last process of Maslow's hierarchy of needs is self-actualization. Altair overcame her fear of losing someone she holds dear and willingly showed an act of self-sacrifice as both sign of her overcoming her internal conflict and her safe space. The fulfillment of her selfactualization has also been cemented as she fully reaches her potential as a creation to become a being at the same pedestal as those of gods.

\section{References}

1. Mambrol, Nasrullah, Literary Criticism of Plato, Online Article, Literariness.org (2017).

2. Aoki, Ei, Re:Creators, animation, Aniplex (2017).

3. Koeswara, E, Teori-Teori Kepribadian: Psikoanalisis, Behaviorisme, Humanistik, Bandung: Eresco (1991)

4. Pratista, Himawan, Memahami Film, Yogyakarta: Homerian Pustaka (2008) 